\title{
There Will be Doubt, But When is Doubt 'Good?
}

\author{
Reflections From an Old Testament Perspective
}

Turning to the Old Testament for perspectives on "doubt « is met with the absence of philological data: there is no word in biblical Hebrew that can be directly translated as »doubt«. One possible method for approaching this topic is to consider the appearance of various Greek terms in the LXX that are often translated as "doubt" in modern translations of the New Testament. There are several possibilities: diastazo: found in Mt 14,31.28,17; diakrino: Mt 21,21; Mk 11,23; Rm 14,23; Js 1,6; Jd 1,22; and dialogismos: Lk 24,38. The term diastazo does not appear in the LXX. Diakrino, when it appears, implies the notion of "judging «: in Ex 18,16 where the Hebrew text uses שפט, "to judge", and elsewhere for "discerning", i.e., 1Kgs 3,9: "judging between": בין. Most promising is dialogismos, which represents the Hebrew מחשבה (»thoughts", Ps 56,6, in LXX 55,6). Its usage in Ps 139,20 (LXX 138,20) parallels that of the New Testament

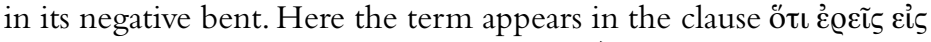

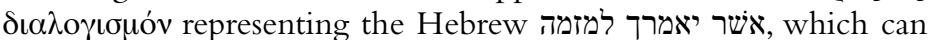
be rendered "those who speak of you maliciously" (NRS).

Nonetheless, it should be quite apparent that the lexical fields rendered with various forms of "doubt/Zweifel " in modern translations for the Greek New Testament do not carry the same connotations in the Old Testament, even when the same terms are used in the LXX translations. Likewise, the term "Zweifel " does not appear in the Old Testament books of the German Zürcherbibel, though it does appear several times in the English NRS most strikingly in Dtn 28,66, where it occurs in a curse: "Your life shall hang in doubt before you; night and day you shall be in dread, with no assurance of your life". The Hebrew term in this case is the hapax legomenon תלאים, the root of which suggests "hanging", thus with implications of terror and suspense. ${ }^{1}$ This lack of philological support may be the reason why

1 In a standard Hebrew-English Lexicon, BDB, 1067, the term is understood as a pu'al participle, and תלה תלא, which never implies something like "terror, doubt, suspense." 
several recent Bible dictionaries only address the NT in their entries on »doubt/Zweifel" if at all. ${ }^{2}$

The meager results from such a philological investigation leads to the search for other means of entry into the thematic of "doubt" in the Old Testament. A second possible approach is to begin with modern definitions, and then proceed by way of thematic resemblances. Consideration of the etymological meanings of the modern German word "Zweifel" or the English »doubt" and French »doute» (from Latin Dubitare) present a very different situation. Zweifel, as is easily seen, derives from the notion of "doppelt, gespalten, zweifach, zwiefältig." An English dictionary, Merrian Websters, proposes for the noun »doubt« the following:

"an uncertainty of belief or opinion that often interferes with decision-making $\mathrm{b}$ : a deliberate suspension of judgment 2: a state of affairs giving rise to uncertainty, hesitation, or suspense $3 \mathrm{a}$ : a lack of confidence: distrust b: an inclination not to believe or accept.»

At the base of both the Germanic and the Latin-based expressions is an uncertainty, often one that leads to an inability to act. One can conclude from the German root that the availability of more than one option leads to a point of decision between them, giving rise to the possibility of indecision. Doubt defined this way is more or less a human given: life presents everyone with many conflicting or dissonant experiences and objects - each person orders this diversity according to both subtly and drastically different principles. Yet, as Kierkegaard noted in his statement, "Doubt comes into the world through faith $\ll^{3}$ one must have some belief in order for doubt to develop: without a basic orientation of trust, no doubt can develop.

\footnotetext{
2 M. Beiner, Art. Zweifel, I. Systematisch-theologisch, TRE 36:767-772 does not discuss the biblical data. In fact, when looking for an entry on doubt in modern reference works, RGG and ABD provide no entry at all, while in NIBD (2:160), S.-K. Wan provides a very short discussion solely of New Testament material.

3 S. Kierkegaard, Journals and Papers, transl. by H.V. and E.H. Hong, Bloomington /Indianapolis, 1976, 1:399 (IV B 13:18,19). J.K.A. Smith (The Devil Reads Derrida and Other Essays on the University, the Church, Politics, and the Arts, Grand Rapids, Michigan, 2009, 14) comments on Kierkegaard's view as follows, "Doubt is not the antithesis or antidote to faith; it is its companion in a way. We might simply put it this way: Only believers can doubt. And in some cases, doubt is faithful precisely where certainty is unfaithful. Some of our doubts - like Thomas's - grow out of our believing the promises of a good and loving God. The lament psalms (e.g., Psalm 77) articulate just this kind of strange paradox: that it is sometimes more faithful to doubt precisely
} 
The only monograph to my knowledge on doubt in the Old Testament seems to take something similar as its starting point. Davidson's The Courage to Doubt begins from the paradox of God's self revelation to the world on one hand contrasted with God's hiddenness on the other, and studies how these two poles are held together in Old Testament spirituality. ${ }^{4}$ Unfortunately, Davidson never actually provides a definition for doubt, nor a matrix for recognizing occurrences of doubt in the Old Testament.

In light of the gap in scholarship with regard to a methodology for addressing doubt in the Old Testament, I will turn to what I see as a one important aspect: the "problem" of universal and everyday human doubt within the juxtaposition of doubt with trust or confidence. ${ }^{5}$

A thematic survey of the possible appearances of doubt yields numerous results across the various genres of the Old Testament - in narratives, wisdom literature, and prophetic literature. For example, Sarah doubts that she will really bear a child (Gen 16.18). In 1 Kings 22 (cf. $1 \mathrm{Kgs} \mathrm{13)}$ opposing prophetic oracles from Yahweh are presented. Job - both in the narrative frame and in the dialogues - addresses the issue. In Genesis 3 the serpent doubts the divine word and invites the humans to share its view. Jeremiah (20,7-18) can be said to shape his doubt in the form of protest, much like the many lament Psalms (i.e., Pss 44.60.74.79.80.84.85.88.90.123.137). These various texts can perhaps best be divided into the following categories: (1) doubt that remains within or a part of a relationship of trust in God, i.e., Job; (2) doubt that questions a trust in God, i.e., 1 Kings 22; and (3) doubt as blatant mistrust, i.e., Genesis 3. Naming three categories allows doubt to be valued both as positive and negative, but it is nonetheless not always clear that all Old Testament texts have these categories in mind: the systemization is certainly my own. Given this range of categories, doubt, in and of itself, is therefore value neutral.

\footnotetext{
when it seems like God's goodness has been eclipsed by the tragic. It's not that we won't believe, but we can't believe."

4 R. Davidson, The Courage to Doubt: Exploring an Old Testament Theme, London /Philadelphia, 1983, esp. x-xi.

5 A further use of the concept of doubt in modern thought is the philosophical method most often associated with Descartes, which attempts to determine an unquestionable epistemological foundation from which an ensuing philosophical structure can be constructed. This methodological doubt will not be the topic of my reflections, as it is unknown in the Old Testament (the method of reflection in Ecclesiastes could be a possible exception, though I would contend otherwise).
} 
The diversity of these texts gives rise, however, to the question of what the distinguishing features of occurrences of doubt might be? One might further question what it is that differentiates doubt from unbelief, or doubt from protest? Unbelief seems to be what a number of New Testament texts have in mind when they condemn what is often translated as doubt: i.e., Matt 14,31 (to Peter), »O you of little faith, why did you doubt (distazo)? " or James 1,6, "ask in faith without any doubting (diakrino), for the one who doubts is like the surf of the sea driven and tossed by the wind." Such dynamics also occur in the Old Testament, for example in Exod 16,20 a number of Israelites disregard (literally "do not listen«: אל ישמעו) Moses' command to gather only manna for one day. Those texts in which doubt takes on the connotations of unbelief fall within my third category.

Yet the Old Testament, also addresses doubt within the context of faith: it is often the believing who doubt, and there are many cases where they are not reproved for their questioning. More often they express their doubts in various forms of protest, thus making it quite difficult to distinguish between protest and doubt. Maybe, then, it is best to see protest as one of a number of possible expressions of doubt. ${ }^{6}$ In recent scholarship this protest has taken on an important role in the formation of Old Testament theologies, especially in that of Walter Brueggemann's Theology of the Old Testament, ${ }^{7}$ which places it as a counterpoint, under the title "counter-testimony" to the prominent "core-testimony", which is the basic salvation-historical storyline. The psalms of lament and Jeremiah's confessions are wellknown examples of this doubt expressed in protest.

Nonetheless, doubt may express itself otherwise as well, in such actions as mourning or laughter. Generally speaking, however, doubt in the Old Testament, in all its forms is, as von Rad comments, "not doubt about the existence of Jahweh [...] but doubt about his readiness to interfere drastically in history or in the life of the individual.$^{8}$ This interpretation encompasses far more than simply protest, mistrust, or weak belief. Rather, protest is one of a number of responses growing out of doubt. In what follows I will investigate several expressions of doubt that show its presence is far broader than simply protest: but also of sadness as in Lam 5,19-22, and laughter in Genesis 17-18. As to why I have chosen these texts, in brief, Lamentations even through its very genre as lyric poetry and both

\footnotetext{
6 This appears to be Davidson's understanding.

7 W. Brueggemann, Theology of the Old Testament, Minneapolis 1997.

Old Testament Theology, 1962, 1:453.
} 
the Genesis texts in their focus on laughter and Lamentations with its sadness put the emotions of doubt on display.

\section{Doubt and Mourning: Lamentations 5,19-22}

Lamentations 5: One of the most touching mentions of doubt appears at the end of Lamentations, a book of five poems reflecting on the destruction of Jerusalem and Judah by the Babylonians in 587/6 B.C.E. and the fact that the city remained in ruins. As Dobbs-Allsopp notes, it is significant that the biblical book eschews the divine voice, unlike its Mesopotamian counterparts, such as "The Lamentation over the Destruction of Sumer and Ur", in which the responsible deity declares that the period of suffering has come to an end. ${ }^{9}$ The final poem begins: »Remember, O Yahweh, what has happened to us! Gaze and see our shame« $(5,1)$. The chapter provides numerous details on the destruction: children became orphans, and people had to purchase even the essentials because they had no property of their own. These circumstances are what lead up to the book's conclusion: (VV. 19-22)

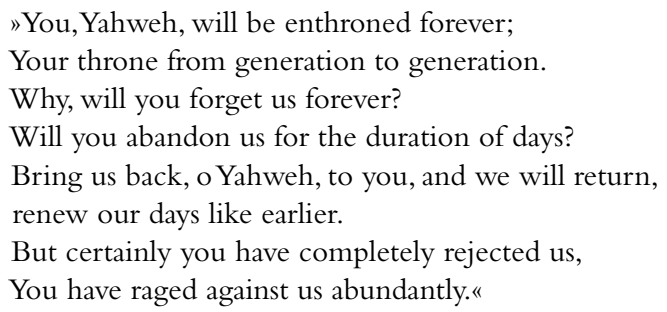

This strophe begins with a trope well known from elsewhere (Pss $10,14-16 ; 80,1-3)$, where it is an utterance of praise. In this context it instead forms the basis for the ensuing doubt, rather than confidence: "If it is true that God reigns forever, then why does the situation continue to remain so tragic?" Following von Rad's formulation, God's lack of readiness to interfere in human history in the specific case of Jerusalem's demise is lamented, so, then, what can one expect of the future? These first three verses (19-21) describe the oscillation from the statement of Yahweh's unbounded kingship, to the uneasiness about the future in light of the current abandonment, and finally to the prayer for restoration. To this point the structure follows a general pattern of laments. This contrast between prior

9 F.W. Dobbs-Allsopp, Lamentations, Interpretation, 2002, 150. 
divine presence and promise on the one hand and the physical suffering of Jerusalem's desolation on the other hand leads to the hard to interpret conclusion of the book in V. 22. The LUT (similar are ZUR, NRS, and NAS) translates a hesitant:

»Hast du uns denn ganz verworfen, und bist du allzu sehr über uns erzürnt?»

On this reading there is no assurance of divine action, but merely a question. What is one to expect for the future? Perhaps Yahweh has forgotten them for the rest of time? However, this reading leaves far more space for the possibility of divine action than that of several recent interpreters who suggest the following interpretation:

"But instead you have completely rejected us; you have been very

angry with us. $\otimes^{10}$

This difference in this interpretation (which matches with my translation above) lies in a different understanding of the first two words of the verse כי אם. The problem with the translation as a question found, i.e., in LUT, is that the Hebrew double conjunction is not typically used to introduce a question. A further possibility is that the verse is an extension of V. 21, therefore reading: »Renew our days like earlier, unless you have completely abandoned us".

Regardless of which reading one opts for - and perhaps some level of ambiguity could be intentional - it remains difficult to find hints of protest in these verses. The eternal nature of the divine throne $(\mathrm{V}$. 19) is simply contrasted with the rejected state of Jerusalem and Judah. The tone is instead pleading: "Bring us back, O Yahweh«. Either this prayer is juxtaposed directly with an observation of Yahweh's rejection, or the prayer is restricted by the statement of Yahweh's rejection and anger. In both cases the presentation of mutually exclusive alternatives at the end of the book comments on the tragedy, the sadness that is the final doubt that the book left with the audience.

The absence of the divine voice in the book as a whole (as mentioned above) along with the accepted canonical status of the book suggest that its perspective has theological approval: faith leads to doubt. Past experience and present emptiness form a cacophonic

\footnotetext{
${ }^{10}$ D.R. Hillers, Lamentations, rev. ed.; AB 7A, New York, 1992, 156, 160-161; A. Berlin, Lamentations, OTL, Louisville, 2002, 115, 125-126. The JPS translation follows this reading of V. 22: "For truly, You have rejected us; Bitterly raged against us. "This translation, in keeping with the rabbinic traditions supporting it then repeats V. 21 in order to provide the book with something of a final denouement, as it also does for the conclusions of Isaiah, Malachi, and Qoheleth.
} 
dissonance. The book itself underlines the possibility and indeed importance for sorrowful lament and deep reflection on previous theological propositions. In these particular verses, the theological question relates (as it does in many places in Lamentations) to the inviolability of Jerusalem: must Yahweh protect Jerusalem from foreign attack as the God of Jerusalem? This Zion theology, as it is commonly known, is called into question by the insistence on God's eternal throne (Yahweh remains God) along with the hesitancy of Yahweh's commitment to restoring Jerusalem. As a result, sadness in the face of tragedy is accepted as a biblically sanctioned expression of doubt. Here, "Lament allows the real experience of suffering in pain, confusion, doubt, and alienation to surface in the context of faith; in other words, a proclamation truly revealing things for what they are«". ${ }^{11}$

\section{Doubt and Laughter: Genesis 17 and 18}

Genesis 17 and 18 offer alternative aetiologies for the name of the future son, Isaac - Hebrew צחק, "He laughs" - that are directly related to their response to the combination of God's pronouncement that they will have a son and their physical state. The two narratives can be understood within their historical-literary contexts as parts of different sources: Genesis 17 is an integral part of the Priestly source, while Genesis 18 comes from an earlier complex that classical scholarship sees as part of the Yahwistic (J) source, while others (those doubting the existence of such a J source) often attribute it to an Abraham-Lot cycle consisting of Genesis 13,18-19. ${ }^{12}$ Both narratives share the thematic of promise-doubt and laughter because of the present circumstances-reassurance. Both narratives also refer to a certain element of inner dialogue: "Abraham laughed and said to himself«; "Sarah laughed to herself, saying ". Nonetheless, each narrative places different accents with regard to their presentation and perspective on doubt.

11 A.M. McCoy, Faith at the Fractures of Life: an Examination of Lament and Praise in Response to Human Suffering with Special Reference to the Theology of Walter Brueggemann and David Ford, University of St. Andrews, 2009, 196.

12 For a formulation of the classical perspective see C. Westermann, Genesis 12-36, BKAT 1/2, Neukirchen-Vluyn, 1981; for rejection of the J hypothesis with regard to Genesis 18, see E. Blum, Die Komposition der Vätergeschichte, WMANT 57, Neukirchen-Vluyn, 1984. 


\section{Abraham's Laughter: Genesis 17}

Genesis 17 as a whole is comprised almost completely of divine speech. The chapter begins with God proclaiming an eternal covenant with Abraham that guarantees him land and a hoard of nations. God changes his name from Abram in the process and pronounces circumcision as the ongoing sign of this bond. In 17,15 God then focuses on Sarai. The first divine action is to change her name to Sarah, thereby matching the action taken with regard to Abraham. While Abraham receives the covenant, Genesis 17 does not grant him any direct blessing. This blessing is reserved for Sarah in V. 16, first in the form of a single son, and then in the form of nations - specifically kings of peoples (God also pronounces blessing on Ishmael at Abraham's request, V. 20).

It is directly in response to God's proclamation of blessing in the form of a son from Sarah by Abraham that the patriarch expresses his doubt.

"Then Abraham fell upon his face, and he laughed. And he said to himself, , Will to a hundred year old man be born, and Sarah?

- will she bear as a ninety year old woman? Then Abraham said

to God, >If only Ishmael might live in your presence!« (Gen

17,17-18)

Surprisingly, this is Abraham's first verbal response to the promise of an eternal covenant including offspring and land in the chapter. God has spoken for the previous 16 verses; space is only allowed for Abraham to fall on his face (V. 3), a clear sign of humility and worship, which is repeated in V. 17 (the repetition, along with the repetitions of God speaking might point to layers of redaction within the chapter, though interpreters are divided on this point). Thus homage sets the initial context for the - then perhaps somewhat surprising initially internal expression of doubt.

The narrator is omniscient in V.17, whether or not God knows of Abraham's internal dialogue does not play a role in the later verses. It is, nonetheless, in Abraham's inner dialogue, thus demonstrating the importance of interiority for the story, that the doubt occurs. Without the report of Abraham's inner thoughts, it might still have been possible to interpret Abraham's answer in V. 18 as stemming from a lack of confidence in the divine promise, though it could also be seen as (solely) concern for his eldest son, Ishmael. With the mention of Abraham's questioning the possibility for him at one 
hundred and Sarah at ninety to have a child, an existential situation that would be termed "doubt" in the modern world arises.

God quickly moves to reaffirm emphatically the promise concerning Sarah (»However, Sarah your wife is about to bear you a son, and you shall name him Isaac«). The use of the emphatic term אבל ("However») and also the reaffirmation of "Sarah, your wife», so that there can be no mistaking the maternity of the promised son, both underline God's attempt to reassure, or possibly to neutralize Abraham's doubts. It is only after this that attention is turned to Ishmael - the one whom Abraham mentions aloud - who also receives a rich blessing (V. 20). Then God returns to the problematic of Sarah's future progeny, remarking that his birth will take place in a year's time, and the covenant will be established through him (V. 21). This marks the end of God's interaction with Abraham, and upon reaffirming the covenant through Isaac, God goes up from Abraham.

Within the story, Abraham's laughter and plea for blessing for Ishmael display an inner dissonance that can be taken as the disruption of a monolithic reality. The contrast between God's spoken promise and Abraham's practical reality exert profound pressure on the human subject. How will he choose to live in the light of such opposing propositions? Abraham chooses laughter, a construct not without a history of its own in modern discourse.

From a philosophical perspective John Caputo suggests,

"Nothing undoes the metaphysics of presence better than laughter. Nothing is more unsettling than laughter. Nothing heals like laughter. Nothing keeps us open like laughter. [...] It is the power to laugh at oneself, one's fears, one's beliefs that liberates and keeps the flux in play, keeps us in movement with the flux, and keeps the openness to the mystery from becoming nostalgia and melancholy, malingering and moping. [...] Laughter ennobles, strengthens, sees one through a bad time. ${ }^{13}$

Caputo's comments are in critique of Martin Heidegger's attempt to ground meaning in some kind of artistic or poetic presence, Heidegger's unrelenting (and ever more esoteric) grasping for the answer to humanity's lack of a knowable foundation for meaning in the present world. Caputo instead turns to Kierkegaard and Nietzsche, two thinkers much more willing to live outside the security of foundationalism. The advantage of the approach taken here by Caputo, as I see it, is that it allows humanity to look the trag-

${ }_{13}$ J. Caputo, Radical Hermeneutics, Bloomington/Indianapolis, 1987, 292-93. 
edies of life full in the face, pick up the pieces, and continue living. This approach provides insight into Abraham's laughter: the ongoing tragedy of childlessness removed the possibility of a grounded foundation of meaning for Abraham within the world as it appeared. Ishmael's birth, however, then allowed him a concrete way forward towards reconciling the world as Abraham experienced it with the divine promise. The divine in-breaking of Genesis 17 does not allow such an easy conclusion. Yet unlike Caputo's perspective, laughter in Genesis 17 does not come as some kind of (Camus-like?) existential response to unaccountable suffering and tragedy - if Nietzschian then mocking the tragedy - but rather in response to a situation that already seems to have overcome the worst through human creativity (a surrogate child through Hagar). What is so striking in this story is that the divine promise, coming after Ishmael's birth, does the unsettling. The humans had found a way out of the agonizing despair of childlessness! Yet in keeping with Caputo's analysis, it is laughter that acknowledges the presence of two realities, it is laughter that expresses the presence of doubt. This laughter - like Caputo's - marks openness, rather than a monolithic monologue of either God's promise or Abraham's experience, thereby creating the possibility for their intermingling that can then lead to a new and unexpected reality.

\section{Sarah Laughs (Last): Genesis 18,9-15}

Genesis 18 takes place at "the oaks of Mamre, "when Abraham showers Yahweh, in the form of three travellers, with rich hospitality. ${ }^{14}$ Abraham's generous meal for the surprise travellers provides the important background setting for the subsequent interactions, in which the contrast between Sarah's »doubt « and laughter in response to God's promise (VV. 8-15) and Abraham's »doubt« or questioning of God's planned destruction of Sodom (VV. 16-33) can be both confusing and instructive. Taken together these two separate narratives can be seen as an extended reflection on the limits, difficulties, and benefits of doubt. Given that the protest elements of VV. 16-33 have been addressed elsewhere, they will not be dealt with here. ${ }^{15}$

\footnotetext{
${ }^{14}$ It is unclear how exactly one should reconcile V.1: "Yahweh appeared to him", with V.2: "And there were three men standing opposite him «. As most commentators remark, there is no need to get caught up in this discrepancy by proposing some kind of "pre-Yahwistic" polytheistic layer or the like.

15 Davidson, Courage to Doubt, 44-48.
} 
With regard to the previous narrative of Genesis 17, I find it most helpful to read the two chapters as reflecting on various stories of the same promise, and they are not necessarily meant to be read chronologically, though this can easily be done without harm. Reading chronologically, however, requires that one comes to some conclusion about Sarah's lack of knowledge about God's promise of a child through her in Genesis 17. Many interpreters that go this route assume that Abraham kept that experience to himself (perhaps a further expression of doubt). I will treat the narrative of Gen 18,1-15 without suggesting that observations from ch. 17 can be understood as known to the authors of Genesis 18.

The description of the rich feast in 18,1-8 portrays Abraham as an able and caring host for all visitors: the fact that Yahweh is present in the three travelers is known to the audience through the narrator's remark in V. 1, but this remains unspoken to Abraham. This initial scene ends with the statement that Abraham stood by them under the tree and they ate (V. 8).

The next scene begins with the unexpected question as to the whereabouts of Sarah, "your wife« (V. 9). Sarah had received brief mention in V. 6 as bread maker in the tent (showing that the narrator and Abraham know where she is), but she is otherwise absent from the feast. Abraham answers the visitors, making known her presence in the tent - at a distance from the feast ${ }^{16}$ these are his last words in the scene. The divine response is emphatic (V. 10): »I will surely return (infinitive absolute + finite verb) to you at the time of life-giving (in nine months), and surely there will be a son for Sarah your wife! « There is no introduction or build up to this pronouncement: it appears unexpectedly. The focus of the action changes settings, from the tree of feasting to the tent of bread making, where Sarah is listening at the entrance. The change in scenery is important because it is only at this point that Sarah - alone at the entrance to the tent (which is behind Abraham) - actively takes the stage as more than a part of Abraham's entourage, while Abraham himself recedes into the background.

Yet the narrator jumps in and provides a further comment, not only on the change of scenery, but also in order to provide background so that the audience can grasp the nature of the guest's (or guests', depending on one's text-critical analysis of VV. 9-10) pronouncement. The audience is told or reminded - depending on whether one is aware of Gen 17,17 or not - that both Abraham and Sarah

${ }^{16}$ J.-L. Ska, The Exegesis of the Pentateuch: Exegetical Studies and Basic Questions, FAT 66; Tübingen, 2009. 
are old. This version of the information on their age includes details only hinted at in Genesis 17: Sarah has gone through menopause. The version in Genesis 17 leaves the details hidden, with both parties no longer able to produce children. Here the woman's status is singled out.

The surprising nature of the promise in the context of especially Sarah's physical state makes her response quite understandable: (V.12) she laughs to herself, literally "in her insides. "The unique choice of laughing together with this phrase ironically plays off the mention of the ceasing of Sarah's "womanly way" (a literal translation) in V. 11, and her own inner question: "[Now,] after I am withered, will this pleasure come to me - and my husband [too] is old!« It seems appropriate, given Ishmael's absence from the narrative, to assume that the role of the surrogate son is not in view, but rather a different set of factors. ${ }^{17}$ Sarah lays down the bare facts of her physical experience: she has no menstrual cycle; she is worn out (בלה). The image is poignant, used elsewhere in the Old Testament for clothing. Her womanhood, if linked as one can assume for the culture and time period directly to her ability to bear children, is limited by wear and tear, and the material only holds out for so long. Sarah's difficulty reconciling the exuberant promise with her heretofore dreary physical reality leads her to laughter. Her laughter can be taken as something more visceral perhaps than Abraham's in the previous chapter. She laughs "in her insides", while in Genesis 17 he laughs openly. Her lack of a menstrual cycle finds its way into the text as a bodily laugh.

Yet there are no words interrupting the visitor's promise in V. 10 and his question or rebuke of Sarah's laugh to Abraham in V. 13. The narrator reports Sarah's inner dialogue, but no record of Abraham's thoughts is provided. Why the shift to the woman? Is Sarah the cipher for them both (perhaps also the case in deuterocanonical Tobit 10,4-5), thus mirroring Abraham's laughter in Genesis 17 ?

At this point (V. 13) the text makes clear (finally) that Yahweh is the one speaking to her - whether Abraham and Sarah are aware of their interlocutor's identity is unstated, though at some point it must become known to them. This also stands in contrast to the narrative in Genesis 17, where there was no question that it was a divine promise of blessing and fertility. On the part of Abraham and Sarah

\footnotetext{
${ }^{17}$ One may again - if Gen 16 and the birth of Ishmael may be taken into consideration - posit Sarah's attempt to rely on Hagar as a surrogate mother as a proposed solution to the dissonance between the divine promise and the heretofore lack of progeny.
} 
in Genesis 18, perhaps this must be intuited, though it seems only to be emerging at this point: who other than a divine being would be able to pronounce such promises? Perhaps her question points to Sarah's lack of recognition of the visitor's divinity? How was she to know that he was Yahweh? Why should she take his words as a trustworthy telling of the future?

Yahweh states, "Why this? Sarah laughed saying: Will even truly I bear [a son]? But I am old! Is anything too hard for Yahweh? I will return to you at the time of life, and for Sarah there will be a son. ${ }^{18}$ Several aspects of this divine word are important for an analysis of Sarah's doubt. First, Yahweh seizes upon Sarah's doubts in his use of two emphatics (אמנם ,אף), neither of which Sarah herself used in her inner dialogue reported in the previous verses. These emphatic words underline her lack of confidence in her own ability to bear a child. Second, the text is unclear as to where Yahweh's quotation of Sarah's words actually ends. Modern translations end the quotation after the statement "But I am old! " However, it is quite possible that the following statement: "Is anything too hard for Yahweh?» (this statement could also be read as an exclamation, rather than a question) also belongs to Sarah's inner dialogue. Attributing this clause to Sarah might be more plausible because otherwise Yahweh uses a third person designation (his own name) to refer to himself. This reading would mean that Yahweh attributes a profound trust, if an exclamation, on Sarah's behalf in Yahweh's ability to reach into her physical reality and change it. The two possible readings of this statement allow the audience to read in their own expectations. Perhaps it is best to ask: is it Sarah who doubts, or rather the reader who doubts? The positive connotations of her laughter agree with her own joyful statement later when Isaac is born, in 21,6 »Sarah said, 'God has made me laugh"«.

The problem with this interpretation comes with Sarah's response when her laughing - her doubt - has been outed. She appears to choose shame by attempting to hid her laughter: "Sarah lied saying, \I did not laugh.« The narrator comments that her lie was birthed in fear. One may also ask here whether the narrator provides an excuse that makes her laughter acceptable: i.e., it is O.K. to lie about laughing if the reason for the lie is fear. ${ }^{19}$ Or, on the other hand, does the

\footnotetext{
${ }^{18}$ It is striking that Yahweh does not speak directly to Sarah, but instead to Abraham about the reason for Sarah's laughter. Abraham never answers.

19 I.e., G.J. Wenham, Genesis, WBC, Waco, TX, 1987, 48: "These remarks of Sarah's show us the basis of her doubts. She laughed not out of cocky arrogance but because a life of long disappointment had taught her not to clutch at straws. Hopelessness, not
} 
author's statement show what was wrong with Sarah's motivation for lying: there was nothing wrong with her laugh, so she did not need to lie and cover it up.

This further question about the reason for the laughter is a decisive difference between the reports of laughter in the two chapters: God simply leaves when finished stating the promises in Gen 17,22, but in Genesis 18 the reason for the laughter is sought. The reader of Genesis 17 is therefore left to fill in a much greater void with regard to Abraham's laughter. Neither Sarah nor Abraham is willing to answer God on the reason for Sarah's laughter in Genesis 18, but here the question is at least asked, and the text portrays a profound avoidance of the question in Sarah's lie.

Neither is her lie allowed to remain hidden. With an abrupt ending to the discussion, Yahweh simply answers "No, but you did lie». The tension remains palatable, but the narrative moves on. What is the audience to do with Sarah? From a modern reader's perspective Sarah does not fare well when she is thrust into the public eye: in both Gen 12,10-20 and later in Genesis 20, public viewing of Sarah lands her in the harem of various rulers. She generally finds safety when hidden among the tents. Yet not even this physical seclusion can protect her in this chapter, for the visitor(s) knows of her presence, who inquires of her whereabouts. She must play a vital role in the story.

\section{Conclusion}

Do Sarah, Abraham, and Lamentations fit the role of the "unbeliever«? Such a determination fits closer with some biblical definitions of doubt, which contrast it with single-minded belief. Yet this does not necessarily fit these examples. One might certainly imagine that Sarah - and Abraham - were puzzled at best with God's method for keeping promises, though they are portrayed as resilient if imperfect followers of their God. As such they may perhaps instead provide a complimentary image to that of some "unbelieving " or "littlefaithed « doubter. ${ }^{20}$ The situation in the New Testament is also more

pride, underlays her unbelief. Her self-restraint in not openly expressing her doubts and the sadness behind them go far to explain the gentleness of the divine rebuke." ${ }^{20}$ This approach is taken by W. Brueggemann, Genesis, Interpretation, Atlanta 1982, 158: "The entire text of Gen. 17 concerns binding Abraham to God in radical faith.Yet by verses 17-18, Abraham completely doubts the promise, laughs a mocking laugh, and appeals to the son already at hand. Abraham, the father of faith, is here again pre- 
complex, of course, as can be seen in the portrayal of "doubting" Thomas (John 20,24-29): his unbelief does not seem to be rejected as a wrong human choice, but rather the consequence of human existence. Doubt in the sense described in Lam 5,19-22; Gen 17.18 is an acceptable - according to the Old Testament texts in which it is found - response from genuine Yahweh-followers to either a tragic situation such as the destruction of Jerusalem or the long, wearying unfulfilled desire for a child. For how is a believer to respond to the stark contrast between Yahweh's specific promises of care for his followers' present and future on the one hand and the ongoing absence of this very care? To bring Caputo's perspective back into view, the laughter - as well as sadness - calls this particular kind of a monolithic "metaphysics of [divine] presence, " the unquestionable divine promises, into question by pointing to the facts on the ground, where the fulfillment of the promises are absent.

— Dr. Peter Altmann ist wissenschaftlicher Assistent am Lehrstuhl für Alttestamentliche Wissenschaft und Frühjüdische Religionsgeschichte an der Universität Zürich.

sented as the unfaithful one, unable to trust, and willing to rely on an alternative to the promise». He also compares them to the unbelieving disciples in Mark 8,14-21. 